\title{
1. Introduction: the emerging field of non-market entrepreneurship
}

\author{
Gordon E. Shockley, Peter M. Frank and \\ Roger R. Stough
}

\section{PART 1. FOUNDATIONS OF NON-MARKET ENTREPRENEURSHIP}

Non-market Entrepreneurship: Interdisciplinary Approaches represents an initial contribution to building a theoretical edifice within the field of entrepreneurship research to encompass the myriad forms of non-market entrepreneurship, which we define as activity that still partakes of entrepreneurial activity (for example opportunity recognition, proactive action, and so on) but not undertaken solely for the purpose of profit maximization or commercialization. As it matures from borrowed to its own terminology and methods (Cornelius, Landstrom and Persson, 2006, p. 376), general entrepreneurship research is one of the most exciting social scientific fields of inquiry with which to be associated nowadays because of its scope, promise and interdisciplinary demands. Non-market entrepreneurship indeed magnifies the excitement of general entrepreneurship research. Certain forms of non-market entrepreneurship have received more attention in the recent past, such as public sector and policy entrepreneurship. Other fields are presently in vogue, such as social entrepreneurship and (depending on the definition) social enterprise. And still others are just being recognized, many of which appear in these pages. Yet, while some attention has been given to the different forms of non-market entrepreneurship, there has been no attempt to look at them synoptically as theoretically related and possibly comprising a coherent field of research, that is to say, the field of non-market entrepreneurship. And there has been no single academic discipline able to satisfactorily contain even the idea of non-market entrepreneurship. Identifying the tentative boundaries for this emerging field is one of the main objectives of Non-market Entrepreneurship: Interdisciplinary Approaches (NME).

Identifying the boundaries of the emerging field of non-market entrepreneurship is only one component of the triad of research, theory and teaching that might be called the 'Foundations of non-market entrepreneurship', 
the title of this volume's first part. The two other chapters in Part 1 complete the triad. Koppl and Minniti's 'Entrepreneurship and human action' provides a philosophical justification for the categorical existence of non-market entrepreneurship. 'A unified and comprehensive theory of entrepreneurship', they argue, 'is possible if and only if we see entrepreneurship as a universal form of human action'. Indeed, the very idea of non-market entrepreneurship as partaking of entrepreneurial activity but not done solely for the purpose of profit maximization or commercialization must depend on entrepreneurship being a universal form of behavior. While Koppl and Minniti find entrepreneurial behavior in the psychology of learning, the innovation and imitation of the great Renaissance artist Raphael, and the sociology and philosophy of Max Weber and Alfred Schutz, this volume further stretches their insight by looking at entrepreneurial activity outside of the commercial sector in the non-market settings of the public and social sectors.

Ashcraft's chapter 'Teaching entrepreneurship outside of business schools' also reaches beyond the commercial sector as it addresses how theories as well as practice of non-market entrepreneurship might be taught in academic units other than business schools, where it is incorrectly assumed entrepreneurship education naturally and exclusively resides. He takes up this vital topic by examining the case of Arizona State University developing a social entrepreneurship offering outside of the business school. 'Business schools', Ashcraft asserts, 'are not the only drivers of social entrepreneurship education in colleges and universities as the field emerges in multi-disciplinary, inter-disciplinary and transdisciplinary ways'. This chapter is particularly timely in that it is to the author's knowledge the first academic paper to incorporate the Nonprofit Academic Centers Council's (NACC) curricular guidelines for both undergraduate and graduate nonprofit education.

\section{PART 2. NON-MARKET ENTREPRENEURSHIP: SOCIETY AND ECONOMY}

Non-market entrepreneurship has implications for the larger society and market economy. This is the theme linking the three chapters of Part 2. In 'Non-market sources of American entrepreneurial capitalism', Acs, Phillips, Audretsch, and Desai discuss the effects of non-market entrepreneurship in relation to the historical phenomenon of American capitalism. The key lies in what they call the 'entrepreneurship-philanthropy nexus'. Their argument is that philanthropy drives a positive feedback loop underlying American capitalism as 'American philanthropists - especially those who have made their own fortunes - create foundations that, in turn, contribute to greater 
and more widespread economic prosperity through opportunity, knowledge creation and entrepreneurship'. The ultimate effect of this non-market entrepreneurship is that it supports the process of economic development and the United States' continued economic dominance.

Boettke and Coyne's 'The political economy of the philanthropic enterprise' is the converse of Acs, Phillips, Audretsch, and Desai's chapter. Instead of looking at the causal effects of philanthropic effects of the economy, they turn the relationship around and look at 'the contributions of for-profit activities to the betterment of society' through the non-market vehicle of philanthropic enterprise. 'We wish to highlight that while charitable donations are one means of giving to society, so is the provision of jobs as well as new products and services available at decreasing costs'. They make the intriguing point that the traditional separation of civil society from the market economy is a false dichotomy and offer as a substitute the distinction between civil society as 'self-governance' and the state as 'enforced order'. Boettke and Coyne conclude that 'philanthropic enterprise is really a function of betting on people, not on projects'.

Anderson, MacAulay, Kayseas, and Hindle's 'On their own terms: indigenous communities, entrepreneurship, and economic development in the New Economy' completes Part 2. In introducing to many readers the concept of 'Indigenous entrepreneurship', Anderson, MacAulay, Kayseas and Hindle take up several themes raised in $N M E$. Like the two preceding chapters in this part, they examine the effects of a form of non-market entrepreneurship (that is, Indigenous entrepreneurship) on society and economy (that is, Indigenous economic development). Like most of the chapters in this volume, it articulates another form of non-market entrepreneurship, which is one of the primary objectives of $N M E$. Like Koppl and Minniti's chapter in Part 1, Anderson, MacAulay, Kayseas, and Hindle's definition of indigenous entrepreneurship exclusively in terms of general entrepreneurship underscores the universality of entrepreneurial activity, thus invoking the first and last chapters and bringing the reader full-circle. And, together with all of the chapters in this book, 'On their own terms: Indigenous communities, entrepreneurship, and economic development in the New Economy' begins to sketch the boundaries of the emerging field of non-market entrepreneurship, which, again, is one of the main objectives of $N M E$.

\section{PART 3. ENTREPRENEURSHIP IN PUBLIC AFFAIRS}

$N M E$ is a Popperian exercise in theory-building for entrepreneurship research. The eminent philosopher of science Karl Popper writes in 
Objective Knowledge (1989): '. . . while we cannot ever have sufficiently good arguments in the empirical sciences for claiming that we have actually reached the truth, we can have strong and reasonably good arguments for claiming that we may have made progress towards the truth . . '(pp. 57-8). Without sound theories to account for all of the entrepreneurial phenomena now being observed within and across the for-profit, nonprofit, and governmental sectors all around the world, the progress of entrepreneurship research will be impeded and our understanding of the diversity, ubiquity, and essence of entrepreneurial activity will be incomplete. Bygrave and Hofer (1991) wrote early in the 1990s that 'a major challenge facing entrepreneurship in the 1990s is to develop models and theories built on solid foundations from the social sciences' (p. 13). While significant progress was indeed made in the 1990s theorizing on commercial forms of entrepreneurship, the theory-building on entrepreneurship was far from being finished. A decade after Bygrave and Hofer, Shane and Venkataraman (2000) write, 'Perhaps the largest obstacle in creating a conceptual framework for the entrepreneurship field has been its definition' (p. 218). To develop theory for entrepreneurship research by thoroughly if not exhaustively articulating the various forms of non-market entrepreneurship is another of $N M E$ 's main objectives.

One way to distinguish the two chapters of 'Entrepreneurship in public affairs' (Part 3) is entrepreneurial activity inside government organizations (Stough and Haynes' chapter) on the one hand and entrepreneurial activity outside in the political environment (Shockley's chapter) on the other. In 'Intrapreneurship in the public sector', Stough and Haynes examine entrepreneurial activity inside public sector organizations by utilizing and stylizing the notion of 'intrapreneurship' for the public sector. In so doing, they accomplish a multi-dimensional comparison piece by contrasting both intrapreneurship from entrepreneurship and intrapreneurship in the public sector from intrapreneurship in the commercial sector, where the notion is popular and relatively well-developed. They then develop the idea of public sector intrapreneurship by applying it to the public-works cases of Robert Moses, William Mulholland and Franklin Delano Roosevelt in the earlier half of the twentieth century. The novelty of their case analyses is not in bringing to light new details of these fairly well-known cases but rather in interpreting already established case information with the theoretical lens of public sector intrapreneurship. Although Stough and Haynes' focus is intrapreneurship within the public sector, this form of non-market entrepreneurship has considerable policy implications for the political environment.

Shockley's 'Policy entrepreneurship: reconceptualizing entrepreneurship in public affairs' reworks the idea of policy entrepreneurship previously 
offered by distinguished political scientists over the last few decades by adapting to policy studies the insights of the classical entrepreneurship theorists Joseph Schumpeter and Israel Kirzner. Based on what he calls the first classical insight (the ubiquity of entrepreneurship in all human endeavors), he reclassifies entrepreneurship in public affairs as policy entrepreneurship emphasizes not the descriptive power of identifying individual policy entrepreneurs as has been preferred in prior research but rather the explanatory power of entrepreneurship in public policy.

\section{PART 4. ONLY A SEMANTIC DIFFERENCE? SOCIAL ENTREPRENEURSHIP, NONPROFIT ENTREPRENEURSHIP, AND SOCIAL ENTERPRISE}

While the theory-building chapters develop and assess different forms of non-market entrepreneurship, there is no single, general theory of entrepreneurship espoused or endorsed in these pages. All of the contributors to this volume were invited to discuss a particular form of 'non-market entrepreneurship' (as defined above) from a theoretical, mostly qualitative perspective without any particular commitment to what constitutes 'entrepreneurship' itself. The four chapters of Part 4 suggest that this open invitation to the contributors has become one of the volume's strengths. Four chapters on entrepreneurship in the social sector are juxtaposed: social enterprise (Young), nonprofit entrepreneurship (Frank), social entrepreneurship (Parker), and social ventures (Yitshaki, Lerner, and Sharir). As the reader engages these chapters, he or she is invited to consider whether the differences between them are real, thus comprising distinct forms of non-market entrepreneurship in the social sector, or whether the differences between the forms are only semantic.

Frank's 'A model of nonprofit and socially motivated entrepreneurial behavior' provides 'a conceptual model to explain the various forms of entrepreneurship that result from socially motivated discovery and creativity'. He develops a typology of entrepreneurial behavior and divides nonprofit entrepreneurship into first nonprofit enterprise, which he defines as 'the entrepreneurial act of discovering or creating innovative approaches to non-market solutions to social problems by establishing a nonprofit organization', and then social enterprise, which he defines as 'the entrepreneurial act of discovering or creating an earned income strategy by a nonprofit or the creation of separate income generating entity by a nonprofit'. Franks' model transcends the for-profit/nonprofit distinction by examining entrepreneurial behavior 'occurring in both the nonprofit and market sectors that is considered, at least in part, to be socially motivated'. 
Instead of distinguishing different forms of non-market entrepreneurship in the social sector, Young in 'A unified theory of social enterprise' brings them all together into a unified theory of demand and supply that accounts for all types of social enterprise. Similar to Frank, Young finds 'cross-sector' social enterprise. Social enterprise can arise from the demand side as consumers might prefer social instead of commercial enterprise, corporations might seek strategic partnerships with nonprofits, and governments seeing efficient or effective provision. Social enterprise can also arise from the supply side in competition for entrepreneurial talent, giving and volunteering behavior, and labor priced below-market cost. Young's unified theory is premised on the idea of nonprofits as multi-product organizations.

Parker takes more of a behavioral approach to entrepreneurship in the social sector. Assuming that the reader already is comfortable with the distinctions between for-profit and social entrepreneurship as well as paid employment and volunteering, Parker wants to the know the 'why' and 'when' of an individual's decision to engage in voluntary social entrepreneurship. 'A key insight from this work', he expresses in the argot of the neoclassical economics, 'is that individuals only become entrepreneurs if they obtain greater than expected utility from entrepreneurship than from paid employment; otherwise, they become employees'. One instantly wants to know if these decisions will vary with different forms of nonmarket entrepreneurship. 'More generally', Parker observes, 'the field of non-market entrepreneurship needs to develop a strong body of empirical work focused on social entrepreneurs', as he has done in his chapter.

Yitshaki, Lerner, and Sharir also have an empirical focus in their chapter on entrepreneurship in the social sector. In 'What are social ventures? Toward a theoretical framework and empirical examination of successful social ventures', they look at social ventures, which (fitting squarely within $N M E$ 's general definition of non-market entrepreneurship) are 'social enterprises that are initiated by individual entrepreneurs not for the purposes of profit maximization or commercialization, but for attaining and implementing various social goals'. Social ventures survive, they find, 'if they have the ability to raise financial resources for ongoing operations, gain legitimacy and draw in followers, and develop personal networks and internal capabilities'. They also identify the scale of operation as an additional factor contributing to the success of a social venture 'a national mode of operation' increased the chances of survival than 'a local or self-help mode of operation'. Theory-building is incomplete without at least recognizing the empirical application of the theories being built. Yitshaki, Lerner, and Sharir's chapter together with Parker's provide that for $N M E$. 


\section{ACKNOWLEDGMENTS}

We gratefully acknowledge many people in the production of Non-market Entrepreneurship: Interdisciplinary Approaches. We first thank Alan Sturmer, Tara Gorvine and Bob Pickens of Edward Elgar, Inc. for their patience and support as we put together what we hope is a top-notch edited volume for scholars of entrepreneurship research. We also heartily appreciate the contributors, most of whom are well-established scholars, for lending their credibility to this volume and treating us with respect and seriousness. No doubt the editorial presence of Dr Roger Stough, whose kind mentorship continues to support us, helped us in this regard. We also very much appreciate the initial financial support from Alan Carsrud and Eugenio Pino and Family Global Entrepreneurship Center at Florida International University, and the E.M. Kauffman Foundation, as well as the financial support from Arizona State University's School of Community Resources and Development (Directors Kathleen Andereck, $\mathrm{PhD}$; Rhonda Phillips, PhD; and Randy Virden, PhD) and College of Public Programs (Dean Debra Friedman, PhD) to finish up the volume.

\section{REFERENCES}

Bygrave, W.D. and Hofer, C.W. (1991), 'Theorizing about entrepreneurship', Entrepreneurship Theory and Practice, 16(2), 13-22.

Cornelius, B., Landstrom, H. and Persson, O. (2006), 'Entrepreneurial studies: the dynamic research front of a developing social science', Entrepreneurship Theory and Practice 30(3), 375-98.

Popper, K. (1989), Objective Knowledge: An Evolutionary Approach, Oxford: Oxford University Press.

Shane, S. and Venkataraman, S. (2000), 'The promise of entrepreneurship as a field of research', Academy of Management Review, 25(1), 217-26. 